\title{
IMPACT OF INCORPORATING GARLIC OR CUMIN POWDER IN LAMBS RATION ON NUTRIENTS DIGESTIBILITY, BLOOD CONSTITUENTS AND GROWTH PERFORMANCE
}

\author{
Soad El-Naggar ${ }^{1 *}$ and E.M. Ibrahim ${ }^{2}$ \\ ${ }^{1}$ National Research Centre, Animal Production Department, Dokki, Giza, 12311, Giza, Egypt \\ ${ }^{2}$ Animal Production Department, Faculty of Agriculture, Minia University, Egypt \\ *Corresponding author E-mail: soadelnaggar75@gmail.com
}

(Received 1/12/2017, accepted 15/1/2018)

SUMMARY

\begin{abstract}
$\mathrm{T}$ his study was designed to investigate the effect of garlic powder (GAP) or cumin powder (CUP) supplementation in growing lambs ration on nutrients digestibility, rumen liquor parameters, blood constituents and growth performance,. Eighteen of growing Barki lambs (averaged 5-6 months of age and weighted $27.5 \pm 0.90 \mathrm{~kg}$ ) were divided into three equal groups ( 6 animals each) in a feeding trial lasted 100 days. Animals were fed on basal diet (control) or supplemented with 2\% GAP (T1) or CUP (T2) of the concentrate feed mixture. The results showed that apparent digestibility of all nutrients and nutritive values as total digestible nutrients $(\mathrm{TDN})$ and digestible crude protein $(\mathrm{DCP})$ were significantly $(\mathrm{P}<0.05)$ higher for lambs fed rations of GAP or CUP compared with those fed the control ration. Ruminal ammonia nitrogen $(\mathrm{NH} 3-\mathrm{N})$ was increased $(\mathrm{P}<0.05)$ for lambs fed rations GAP or CUP compared with those fed the control, however ruminal $\mathrm{pH}$ and TVFA's were comparable among the experimental treatments. The values of $\mathrm{N}$ balances and dietary $\mathrm{N}$ utilization were increased $(\mathrm{P}<0.05)$ for lambs fed GAP supplemented ration compared with those fed control or CUP-supplemented diet. Meanwhile Average daily gain and feed conversion were higher $(\mathrm{P}<0.05)$ for lambs fed GAP or CUP than those fed control ration. Dry matter intake was comparable among the experimental treatments. There were no significant differences in plasma albumin and cholesterol concentrations among treatments, while plasma concentrations of total protein, globulin and total antioxidant capacity were higher $(\mathrm{P}<0.05)$ for lambs fed GAP or CUP than those fed control ration. Plasma triglycerides concentrations was higher $(\mathrm{P}<0.05)$ for lambs fed CUP than those fed GAP or control. Plasma malonaldhyed (MDA) was decreased $(\mathrm{P}<0.05)$ for lambs fed rations of GAP or CUP than those fed control ration. There was a decrease $(\mathrm{P}<0.05)$ in plasma concentrations of HDL with feeding CUP ration and levels of LDL with feeding GAP compared to feeding the control ration. This study showed that dietary supplementation of either garlic or cumin powder at $2 \%$ significantly improved nutrients digestibility and growth performance in growing lambs, without any adverse effect on rumen fermentation.
\end{abstract}

Keywords: garlic, cumin, nutrients digestibility, growth performance, rumen liquor parameters, plasma biochemical parameters, lambs.

\section{INTRODUCTION}

Using chemical additives, especially antibiotics, may result in accumulation of chemical residues in animal products, causing harmful effects for consumer (Foroozandeh and Ghaffari, 2015). Recently, using of supplemental herbal feed additives, in animal nutrition, has been paid more attention due to concerns of food safety and human health. The beneficial effects of such bioactive herbal additives may be included stimulation of animal appetite and feed intake, improvement of endogenous digestive enzyme secretion, enhancing immune response also, antibacterial, antiviral and antioxidant actions (Toghyani et al., 2011).

Garlic (Allium sativum) is an herb or spice plant that has been used as a source of antimicrobial agents for the gastro-intestinal tract (GIT). The extracts of these plant herbs have been shown to be manipulated ruminal fermentation, improving nutrient utilization in ruminants and maintain the 


\section{El Naggar and Ibrahim}

microbial ecosystem of the GIT especially in tropical regions in order to enhance their productivity (Busquet et al., 2005; Wanapat et al., 2008 b and Patra- Kamra et al., 2011). Modulatory effects of garlic on antioxidant, antitumor and immune functions have been detected (Mohammadi and Oshaghi , 2014 and Schäfer and Kaschula, 2014). Cumin (Cuminum cyminum) is an annual herb and has been used as medicine and spices in food. Dietary supplementation of cumin could either influence the feeding pattern or growth of favorable microorganisms in the rumen. Also, stimulate the secretion of various digestive enzymes, which in turn may enhance the efficiency of nutrients utilization of animals (Patil et al., 2017). Essential oil of cumin acts as powerful internal or external antiseptic, antiinflammatory, an analgesic, hemolytic and anti-enzymatic actions (Guenther, 1950). So, cumin as feed additives has many beneficial effects due to its aforesaid properties in improving nutrient utilization. Cumin as natural antioxidant was effective to improve rumen ecology of mastitis dairy cow's (Nurdin and Arief (2009).

Few studies have investigated the effects of garlic and cumin on feed intake, ruminal fermentation, digestion and performance in ruminants (Patil et al., 2017 and Sahli et al., 2018). There is also little information on the optimum levels of these feed additives on practical on-farm options for significantly improving productivity.The objective of this study was to study the effect of dietary supplementation of garlic or cumin powder on nutrients digestibility, rumen liquor parameters, plasma biochemical indicators and growth performance of Barki lambs.

\section{MATERIALS AND METHODS}

\section{Experimental design:}

This study used 18 of Barki lambs (average weight $27.50 \pm 0.9 \mathrm{~kg}$ and aged 5-6 months old). The experiment was carried out at El-Nubaria experimental and production Station - National Research Centre during the months from March to June 2017.

Animals were fed on concentrate feed mixture (CFM) and peanut hulls at 70 and $30 \%$, respectively to cover their nutrients requirements according to their live body weight (NRC, 2007). The CFM contained $60 \%$ ground yellow corn, $22 \%$ wheat bran, $15 \%$ soybean meal, $1.5 \%$ limestone, $1 \%$ salts and $0.5 \%$ minerals and vitamins mixture. The animals were randomly divided into three equal groups (6 lambs each) of similar initial body weights. The lambs of control group were fed on basal diet (control) or supplemented with $2 \%$ GAP (T1) or CUP (T2) of concentrate feed mixture.

The animals were housed inside window stables for feeding lot groups. Feed were offered twice a day at $8 \mathrm{am}$ and $2 \mathrm{pm}$ and drinking water were available along the experiment. The measurements of lambs' body weights were recorded at starting of the experiment and biweekly thereafter, while feed intakes recorded daily. Averages of daily gain and feed conversion rates of lambs were calculated. All the parameters were recorded at the morning before animals access to feed or water.

\section{Digestibility, $N$-balance and rumen fermentation:}

At the end of the experimental period, three digestion trials were carried out to determine nutrients digestibility, feeding values and nitrogen balance of tested rations by using metabolic cages. Three animals from each group were fed individually for 14 days experimental period, 7 days for adaptation and 7 days for collection period. Feces and urine were collected quantitatively daily during the collection period as described by Maynard et al., (1979). Amounts of feed intake, feces and urine were measured and recorded daily. Solution of $10 \% \mathrm{H}_{2} \mathrm{SO}_{4}$ was added to the representative feces samples before drying in oven at $60{ }^{\circ} \mathrm{C}$ for $24 \mathrm{hrs}$. Dried samples were ground to pass through 1-mm sieve, and kept in closely tied jars for laboratory analysis. Urine were collected daily in glass bottles contain 50 $\mathrm{ml}$ diluted sulfuric acid $(10 \%)$. A representative samples $(10 \%)$ of urine volume were stored for nitrogen determination. Rumen fluid samples were taken from each animals at zero and $3 \mathrm{hrs}$. post feeding using stomach tube. Rumen fluid $\mathrm{pH}$ was measured immediately using digital $\mathrm{pH}$ meter, and then samples were filtered through four layers of sheath cloth. Two drops of diluted formalin solution (10\%) was added to stop microbial activity, acidified and kept frozen at $-20^{\circ} \mathrm{C}$ for the determination of ammonia (NH3-N) according to Conway (1957) and total volatile fatty acids (TVFA's) as described by Warner (1964).

\section{Dietary Sampling and laboratory analysis:}


Dietary samples were collected daily in the last week of each month along the experiment period and a composite sample was performed. A portion of the composite sample was dried at $105{ }^{\circ} \mathrm{C}$ in a forced air oven till constant weight for DM determination. The rest of composite sample was dried at $70{ }^{\circ} \mathrm{C}$ for a constant weight, ground and kept in closely tied jars for laboratory analysis. Diets and fecal samples were analyzed for dry matter (DM), organic matter (OM), crude protein (CP), crude fiber (CF), ether extract (EE) and ash according to AOAC (2012). Nitrogen free extract (NFE) was calculated by the difference. Approximate analysis of CFM, GAP, CUP and peanut hulls are presented in Table (1); while the approximate analyses of experimental diets are presented in Table (2).

Table (1): Approximate analysis of concentrate feed mixture (CFM), garlic powder (GAP), cumin powder (CUP) and peanut hulls fed to growing Barki lambs on DM basis (\%).

\begin{tabular}{lcccc}
\hline Item & CFM & GAP & CUP & Peanut hulls \\
\hline DM & 89.76 & 91.01 & 93.06 & 90.2 \\
OM & 94.50 & 93.03 & 90.58 & 89.80 \\
CP & 14.73 & 13.84 & 16.81 & 9.43 \\
EE & 3.60 & 2.99 & 15.56 & 4.00 \\
CF & 5.50 & 19.63 & 19.38 & 23.79 \\
NFE & 70.67 & 56.57 & 38.83 & 52.58 \\
Ash & 5.50 & 6.97 & 9.42 & 10.20 \\
\hline
\end{tabular}

Table (2): Approximate analysis of experimental diets fed to growing Barki lambs on DM basis $(\%)$.

\begin{tabular}{lccc}
\hline Item & Control & T1 & T2 \\
\hline DM & 89.89 & 91.17 & 91.19 \\
OM & 93.09 & 94.39 & 94.36 \\
CP & 13.14 & 13.33 & 13.38 \\
EE & 3.72 & 3.76 & 3.94 \\
CF & 10.99 & 11.26 & 11.26 \\
NFE & 65.24 & 66.03 & 65.79 \\
Ash & 6.91 & 7.01 & 7.04 \\
\hline
\end{tabular}

\section{Plasma constituents' analysis:}

Heparinized blood samples were collected from the jugular vein of each animal at the end of feeding trials. Plasma samples were obtained by centrifugation of samples at 4000 r.p.m for 20 minutes and stored at $-20^{\circ} \mathrm{C}$ for later assay. Plasma total protein, albumin, total cholesterol, HDL-cholesterol, LDL- cholesterol, triglyceride were determined using colorimetric methods using specialized kits (Salucea, Haansberg, Netherlands). Total antioxidant capacity (TAC) and malonaldhyed (MDA) were determined using colorimetric methods (Biodiagnostic, Egypt).

\section{Statistical analysis:}

Data were subjected to statistical analysis as one-way analysis of variance according to SPSS (2008). The model used to analyze the different treatments studied for lambs was as follows:

$$
\mathrm{Y}_{\mathrm{ij}}=\mu+\mathrm{Ti}+\mathrm{eij}
$$

Where: Yij $=$ Observation, $\mu=$ Overall mean; $\mathrm{Ti}=$ Effect of $i^{\text {th }}$ treatments and $e i j=$ Experimental error. Duncan's Multiple Range test was used to detect differences between means of the experimental groups (Duncan, 1955).

\section{RESULTS AND DISCUSSION}

\section{Proximate analysis:}




\section{El Naggar and Ibrahim}

Data presented in Table (1) illustrated the proximate analysis of CFM, GAP, CUP and Peanut hulls. These results showed that, the CP concentrations were 14.73, 13.84 and $16.81 \%$ for CFM, GAP and CUP, respectively. The EE concentrations of GAP and CUP were 2.99 and $15.56 \%$, respectively. In this respect, Lewis (1984) and Amagase et al., (2001) found that GAP and CUP contained 2-5 and 15 $\%$ EE on DM basis, respectively. The proximate analysis of whole rations is shown in Table (2). The concentrations of all nutrients were almost comparable among the experimental diet. It is acceptable that CP content of whole rations was similar to the recommendation of NRC (2007) for growing lambs diet.

\section{Nutrients digestibility and nutritive values:}

The data presented in Table (3) showed that digestibility of DM, OM, CP, EE, CF and NFE were higher $(\mathrm{P}<0.05)$ for lambs fed GAP (T1) and CUP (T2) supplemented diets than those fed control. However, the digestibility of lambs fed $\mathrm{T} 1$ and $\mathrm{T} 2$ were almost comparable. The results of nutritive values indicated that the DCP and TDN values were increased $(\mathrm{P}<0.05)$ with feeding $\mathrm{T} 1$ and $\mathrm{T} 2$ compared with those fed control.

Table (3): Effect of garlic powder (GAP) or cumin powder (CUP) supplementation on nutrients digestibility and nutritive values of experimental treatments (mean \pm SEM).

\begin{tabular}{|c|c|c|c|c|}
\hline Parameter & control & GAP & CUP & SEM \\
\hline \multicolumn{5}{|c|}{ Nutrients digestibility (\%) } \\
\hline DM & $76.66 \mathrm{~b}$ & $79.87 \mathrm{a}$ & $80.22 \mathrm{a}$ & 0.63 \\
\hline $\mathrm{OM}$ & $78.65 b$ & $82.12 \mathrm{a}$ & $81.76 \mathrm{a}$ & 0.63 \\
\hline $\mathrm{CP}$ & $73.36 b$ & $77.43 \mathrm{a}$ & $77.33 \mathrm{a}$ & 0.77 \\
\hline $\mathrm{EE}$ & $73.68 b$ & $77.58 \mathrm{a}$ & $77.49 \mathrm{a}$ & 0.77 \\
\hline $\mathrm{CF}$ & $57.06 \mathrm{~b}$ & $63.09 \mathrm{a}$ & $65.48 \mathrm{a}$ & 1.42 \\
\hline NFE & $81.20 \mathrm{~b}$ & $85.12 \mathrm{a}$ & $84.39 \mathrm{a}$ & 0.72 \\
\hline \multicolumn{5}{|c|}{ Nutritive value (\%) } \\
\hline DCP & $9.64 b$ & $10.32 \mathrm{a}$ & $10.35 \mathrm{a}$ & 0.13 \\
\hline TDN & $74.69 \mathrm{~b}$ & $79.83 a$ & $79.91 \mathrm{a}$ & 0.90 \\
\hline
\end{tabular}

$a, b$ Means within the same row having different superscripts significantly different $(* P<0.05)$.

These results are in good agreement with similar observation that supplemental GAP had improved CP digestibility (Wanapat et al., 2008 a, b), DM and OM digestibility (Patra- Kamra et al., (2011) and Mirzaei et al., (2012). The results also reinforced by a recent study showed that dietary GAP supplementation increased $(\mathrm{P}<0.05)$ in vitro digestibility of DM (Sahli et al., (2018). The significant improvement in nutrients digestibility noticed in the present study on lambs and reported by others (Zafarian and Manafi, 2013), may be referred as a result of GAP includes an oil containing organosulfur which could act as an antibacterial agent.

In the present study, supplemental CUP was effective to increase nutrients digestibility and nutritive values than control. These results agree with those reported by Khan and Chaudhry (2010) and Kurniawati et al., (2017) who found that the digestibility of DM and OM were higher with feeding CUP than control. In addition, Cardozo et al., (2005) reported that CUP supplementation increased CP digestibility.

The improvement noticed in nutrients digestibility with feeding CUP, in the present study, may be due to that cumin stimulates the secretion of pancreatic enzymes, compounds necessary for proper digestion and nutrient assimilation, and may also have anti- carcinogenic properties which improve animal status as reported by Nurdin and Arief (2009), and also improve cellulose digestion (Kilic et al., 2011) as well as increase CF digestibility. In addition, the observed increase in nutrients digestibility with feeding GAP or CUP could be ascribed as a result of the antimicrobial properties of garlic and cumin which could lead to suppressed rumen digestion (Ikyume et al 2017).

\section{Nitrogen balance and rumen liquor parameters:}

Data presented in Table (4) showed that lambs fed GAP -supplemented diets had higher $(\mathrm{P}<0.05)$ values of nitrogen balance and dietary $\mathrm{N}$ utilization as a percentage from nitrogen intake and digestible nitrogen than those fed control or CUP-supplemented diet. While, there were no significant differences 
between CUP and the control diet. These findings are in good agreement with similar observation reported by Wanapat et al. (2008 a, b). They found an increase in nitrogen balance and nitrogen absorption when cattle were fed ration contained GAP.

The results in Table (5) showed no significant differences in ruminal $\mathrm{pH}$ and TVFA's concentrations among the experimental treatments. The results are consistent with similar observations reported by Ikyume et al., (2017) and Kurniawati et al., (2017). These findings could be indicated that GAP or CUP supplementation had no adverse effect on rumen fermentation.

Table (4): Effect of experimental diets on nitrogen utilization (mean $\pm \mathrm{SEM}$ ).

\begin{tabular}{lcccc}
\hline Parameter & Control & GAP & CUP & SEM \\
\hline N intake, g/h/d & 29.88 & 30.08 & 33.59 & 0.60 \\
Fecal nitrogen, g/h/d & $7.30^{\mathrm{a}}$ & $6.23^{\mathrm{b}}$ & $6.99^{\mathrm{ab}}$ & 0.33 \\
Urinary nitrogen, g/h/d & $10.2^{\mathrm{a}}$ & $7.27^{\mathrm{b}}$ & $12.18^{\mathrm{a}}$ & 0.82 \\
Nitrogen balance, g & $12.38^{\mathrm{b}}$ & $16.58^{\mathrm{a}}$ & $14.42^{\mathrm{ab}}$ & 0.70 \\
Dietary N utilization, \%: & & & \\
of N intake & $41.43^{\mathrm{b}}$ & $55.12^{\mathrm{a}}$ & $42.93^{\mathrm{ab}}$ & 2.44 \\
of digestible N & $54.82^{\mathrm{b}}$ & $69.52^{\mathrm{a}}$ & $54.25^{\mathrm{b}}$ & 3.11 \\
\hline a,b Means have different superscripts in the same row are significantly different at $(P<0.05)$. & &
\end{tabular}

Table (5): Effect of experimental diets on rumen parameters (mean \pm SEM).

\begin{tabular}{lcccc}
\hline Parameter & Control & GAP & CUP & SEM \\
\hline Ruminal $\mathrm{pH}$ & & & & \\
Zero time & 6.33 & 6.33 & 6.33 & 0.06 \\
3 h after feeding & 5.43 & 5.37 & 5.40 & 0.04 \\
Overall means & 5.88 & 5.85 & 5.87 & 0.04 \\
$\mathrm{NH}_{3}$-N, mg/ ml RL & & & & \\
Zero time & $19.80^{\mathrm{b}}$ & $23.40^{\mathrm{a}}$ & $22.63^{\mathrm{a}}$ & 0.58 \\
3 h after feeding & $24.21^{\mathrm{c}}$ & $34.40^{\mathrm{a}}$ & $28.40^{\mathrm{b}}$ & 1.52 \\
Overall means & $22.01^{\mathrm{b}}$ & $28.50^{\mathrm{a}}$ & $25.52^{\mathrm{a}}$ & 0.53 \\
TVFA's, meq/dl RL & & & & \\
Zero time & 5.37 & 4.67 & 4.63 & 0.18 \\
3 h after feeding & 9.17 & 10.53 & 9.67 & 0.38 \\
Overall means & 7.27 & 7.60 & 7.15 & 0.85 \\
\hline
\end{tabular}

$a, b, c$. Means with different superscripts in the same row differ significantly $(P<0.05)$.

The data of $\mathrm{NH}_{3}-\mathrm{N}$ values in Table (5) showed that ammonia values were greater $(\mathrm{P}<0.05)$ with feeding GAP and CUP-supplemented rations than control. Also, there were a significant increase $(\mathrm{P}<0.05)$ in $\mathrm{NH}_{3}-\mathrm{N}$ values with feeding GAP-supplemented rations compared to control or CUP. Similar effects of supplemental GAP on $\mathrm{NH}_{3}-\mathrm{N}$ were detected by Yang et al,. (2007), Kongmun et al., (2010) and Sahli et al., (2018). Ruminal NH3-N considered the most important nitrogen source for synthesis of microbial protein in the rumen (Wanapat and Pimpa, 1999). This may explain the beneficial effects of GAP and CUP on animal metabolism and nutrients digestibility signifying their 


\section{El Naggar and Ibrahim}

role in improving rumen fermentation and feed utilization, stimulating rumen microbial activity, digestive microorganisms or enzyme activity.

\section{Productive performance:}

Data presented in Table (6) showed that averages of IBW and FBW were comparable for lambs fed control, GAP or CUP supplemented diet. Average daily gain $(\mathrm{ADG})$ were increased $(\mathrm{P}<0.05)$ for lambs fed GAP and CUP compared with those fed control. However, there were no significant differences in ADG between T1 and T2. Data showed no significant differences in averages of feed intakes of peanut hulls, CFM and TDM for lambs fed GAP and CUP compared with control. Meanwhile, the intakes of DCP and TDN were tended to increase for lambs fed GAP and CUP compared with those fed control. The results also indicated that feed conversion (FC) of DM (FC-DM), DCP (FC-DCP) and TDN (FCTDN) were significantly $(\mathrm{P}<0.05)$ improved for lambs fed GAP and CUP compared with those fed control.

Table (6): Effect of experimental diets on productive performance of growing Barki lambs (mean \pm SEM).

\begin{tabular}{lcccc}
\hline Parameter & control & GAP & CUP & SEM \\
\hline Body weight: & & & & \\
Initial body weight (kg) & 28.70 & 27.75 & 27.37 & 0.84 \\
Final body weight (kg) & 48.62 & 50.37 & 49.13 & 0.89 \\
Daily gain (g/day) & $199.25^{\mathrm{b}}$ & $226.25^{\mathrm{a}}$ & $217.5^{\mathrm{a}}$ & 3.95 \\
Feed intake: (g/head/day) & & & & \\
Peanut hulls & 465 & 468 & 450 & 0.03 \\
CFM & 1082 & 1092 & 1032 & 0.04 \\
TDM & 1547 & 1560 & 1482 & 0.01 \\
DCP & 149.1 & 161.0 & 153.4 & 0.09 \\
TDN & 1155.5 & 1245.4 & 1184.3 & 0.11 \\
Feed conversion: & & & & \\
FC-DMI/kg gain & $7.76^{\mathrm{a}}$ & $6.90^{\mathrm{b}}$ & $6.81^{\mathrm{b}}$ & 0.13 \\
FC-DCPI/gain & $0.748^{\mathrm{a}}$ & $0.712^{\mathrm{b}}$ & $0.705^{\mathrm{b}}$ & 0.07 \\
FC-TDNI/gain & $5.799^{\mathrm{a}}$ & $5.504^{\mathrm{b}}$ & $5.445^{\mathrm{b}}$ & 0.05 \\
\hline
\end{tabular}

$a, b$ Means within the same row having different superscripts significantly different $(* P<0.05)$.

The present results indicated that supplemental GAP and CUP improved $(\mathrm{P}<0.05)$ the averages of ADG of lambs could be related to the increase $(\mathrm{P}<0.05)$ in their nutrients digestibility, DCPI, TDNI and nutritive value of DCP and TDN (Table 3). Similar effects of supplemental GAP on ADG were detected in buffalo calves (Duvvu et al., 2018). In the same way, a significant increase in ADG has been reviewed with dietary supplemental GAP in lambs (Badias and Yaniz, 2004) and in crossbred calves (Ghosh et al., (2010) and Balamurugan et al., (2014). Also, Ikyume et al., (2017) that garlic powder supplementation up to $1.5 \%$ in concentrate diet of goats did not exert any adverse effect on performance.

In the present study, supplemental GAP had beneficial effect to improve productive performance such as ADG, FC-DM, FC-DCP and FC-TDN of lambs (Table, 6). These results were supported by the findings of Duvvu et al., (2018) who reported that growth rate and feed conversion efficiency were significantly enhanced $(\mathrm{P}<0.01)$ when buffalo calves fed diets supplemented with garlic compared to those fed control. This result may be related to the compound allicin, in garlic, which promotes the performance of the intestinal flora thereby enhancing digestion and improved growth rates (Pourali $e t$ al., 2010).

The present study illustrated that the differences in feed intakes of peanut hulls, CFM and TDMI were not significantly differ among lambs fed GAP and CUP compared with control. This result is consistent with similar observations in beef cow or goats fed garlic (Wanapat et al., 2013 and Rasoul et al., 2014); and lactating goat fed dietary supplemental cumin (Miri et al., 2013). 


\section{Plasma biochemical indicators:}

Data presented in Table (7) showed that lambs fed GAP- or CUP-supplemented diets had higher $(\mathrm{P}<0.05)$ values of plasma total protein $(\mathrm{TP})$ and globulin concentrations $v s$. control. However, albumin concentrations were comparable among the experimental diets. Such increment could be related to a significant improvement noticed in CP digestibility, DCPI and nutritive value of DCP for lambs fed GAP and CUP. This response was also noticed in goats fed diet-supplemented garlic on (Kholif et al., 2012) and Ikyume et al., (2017).

Table (7): Effect of garlic powder (GAP) or cumin powder (CUP) supplementation on plasma biochemical parameters of growing Barki lambs (mean \pm SEM).

\begin{tabular}{lcccc}
\hline Parameters & Control & GAP & CUP & SEM \\
\hline Total protein, g/dl & $6.45^{\mathrm{c}}$ & $6.83^{\mathrm{b}}$ & $7.96^{\mathrm{a}}$ & 0.23 \\
Albumin, g/dl & 3.13 & 3.04 & 3.15 & 0.03 \\
Globulin, g/dl & $3.32^{\mathrm{c}}$ & $3.79^{\mathrm{b}}$ & $4.81^{\mathrm{a}}$ & 0.23 \\
Cholesterol, mg/dl & 75.93 & 75.32 & 76.00 & 0.97 \\
Triglycerides, mg/dl & $28.10^{\mathrm{b}}$ & $30.35^{\mathrm{b}}$ & $34.94^{\mathrm{a}}$ & 1.12 \\
HDL, mg/dl & $35.13^{\mathrm{a}}$ & $32.09^{\mathrm{ab}}$ & $30.78^{\mathrm{b}}$ & 0.78 \\
LDL, mg/dl & $41.24^{\mathrm{a}}$ & $37.90^{\mathrm{b}}$ & $41.60^{\mathrm{a}}$ & 0.64 \\
MDA, nmol/ml & $4.01^{\mathrm{a}}$ & $2.57^{\mathrm{b}}$ & $2.63^{\mathrm{b}}$ & 0.26 \\
TAC, mM/l & $0.84^{\mathrm{b}}$ & $1.51^{\mathrm{a}}$ & $1.37^{\mathrm{a}}$ & 0.11 \\
\hline
\end{tabular}

$a, b, c$. Means with different superscripts in the same row differ significantly $(P<0.05)$.

The differences in plasma cholesterol concentrations, in the current study, were not significantly different between treatments. However, plasma concentrations of HDL were decreased $(\mathrm{P}<0.05)$ for lambs fed CUP compared with those fed GAP and control. Also, lambs fed GAP and CUP had a lower $(\mathrm{P}<0.05)$ LDL concentrations compared with those fed control diet. This finding agrees with similar trend of unchanged blood cholesterol concentrations in sheep fed garlic (Adewumi, 2008). In the same way, Foroozandeh and Ghaffari (2015) observed that blood cholesterol was not significantly affected by the supplemental cumin. Data revealed that plasma triglycerides concentrations were increased $(\mathrm{P}<0.05)$ for lambs fed CUP compared to those fed GAP or control diet. In this respect, Sabry et al., (2017) showed that dietary supplementation of garlic powder proved to have positive effect on growth performance and serum lipid profile. On the other hand, GAP and CUP supplementation decreased $(\mathrm{P}<0.05)$ MDA concentration compared to control. The decrease in MDA concentrations with dietary supplemental garlic was also detected in rat (Sabry et al., 2017).

The data indicated that plasma TAC concentrations were higher $(\mathrm{P}<0.05)$ with feeding GAP and CUP than control. In this way, Juhaimi and Ghafoor, (2013) stated that phenolic compounds content of cumin is responsible for improving antioxidant activities. Also, Park et al., (2009) found that garlic and cumin oils led to high antioxidant activity due to phenolic and flavonoids content.

\section{CONCLUSION:}

Based on the present results, it could be concluded that dietary supplementation of either garlic or cumin powder at $2 \%$ was significantly effective to improve the nutrients digestibility and productive performance in growing lambs without any adverse effect on their rumen fermentation. These improvements were concomitant with favorable signs in plasma biochemical parameters related to immune and antioxidant status. 


\section{El Naggar and Ibrahim}

\section{REFERENCES}

Adewumi, M.K. (2008): Complementary effects of raw garlic and water-washed Neem fruit on in vitro gas production characteristics and blood chemistry of West African dwarf sheep. Tropical Anim. Prod. Investment, 11(1): 07-12.93.

Amagase, H., B.L. Petesch, H. Masuura, S. Kasuga and Y. Itakura (2001): Intake of garlic its bioactive component. J Nutr, 131:955-962.

AOAC., (2012). Official Methods of Analysis of AOAC International, 19 ${ }^{\text {th }}$ Ed. Vol.1, "Animal feed". Maryland, USA, chapter 4:1-77.

Badias, G. and J. Yaniz (2004): Effect of addition of aromatic plants in feed for lambs on daily weight gain and production index. Georgica 10: 11.

Balamurugan, N.; S. M. Sundaram; T. Sivakumar and J. S. I. Rajkumar (2014): Effect of Garlic (Allium sativum) Supplementation on the Growth Performance of Crossbred Calves. Animal Production. 16: $78-87$.

Busquet, M., S. Calsamiglia, A. Ferret, M.D. Carro and C. Kamel (2005). Effects of cinnamaldehyde and garlic oil on rumen microbial fermentation in a dual flow continuous culture. J. Dairy Sci., 88: 2508-2516.

Cardozo, P.W., S. Calsamigila, A. Ferret and C. Kamal. (2005) Screening for the effect of natural plant extracts at different $\mathrm{pH}$ on in vitro rumen microbial fermentation of a high-concentrate diet for beef cattle. J. Anim. Sci., 83: 2572-2579.

Conway, E.H. (1957). Micro diffusion analysis and volumetric error. $5^{\text {th }}$ Ed. Crosby Lockwood and Sons Ltd., London.

Duncan, D.B. (1955). Multiple Rang and Multiple F-Test Biometrics, 11: 1- 42.

Duvvu, M. V.; K. A. Rao; C. V. Seshaiah and D. S. Kumar (2018): Effect of Garlic Supplementation on the Growth Performance andBody Condition Score in Murrah Buffalo Calves. Int. J. Curr. Microbiol. App. Sci (7(2): 2972-2977.

Foroozandeh, A.D. and M. Ghaffari. (2015). The effects of feeding different levels of Cuminum cyminum L. on milk yield and composition and some blood metabolites of Holstein dairy cows. Proceedings of the IRES $4^{\text {th }}$ International Conference, Kuala Lumpur, Malaysia.

Ghosh, S., R.K. Mehla, S.K. Sirohi and S.K. Tomar. (2010). Performance of crossbred calves with dietary growth in crossbred heifers fed paddy straw ration: supplementation of garlic extract. J. Animal Physiology and Animal Nutrition, 95: 449-455.

Guenther, E. (1950). The Essential Oils. $3^{\text {rd }}$ Ed. D. Van Nostrand, New York.

Ikyume, T.T., O.S. Sowande, P.A. Dele, A.O. Yusuf and S. Monday. (2017). Effect of varying levels of garlic (Allium sativum) powder on growth, apparent nutrient digestibility, rumen ecology, blood profile and cost analysis of feeding West African Dwarf goats. Mal. J. Anim. Sci., 20(2): 61-74.

Juhaimi, A.L. and K. Ghafoor. (2013). Extraction optimization and in vitro antioxidant properties of phenolic compounds from Cumin Cuminum cyminum L. seed. International Food Research Journal, 20:1669-1675.

Khan, M.M.H. and A.S. Chaudhry. (2010). Chemical composition of selected forages and spices and the effect of these spices on In vitro rumen degradability of some forages. Asian-Just. J. Anim. Sci., 23: 889-900.

Kholif, S. M.; T. A. Morsy and M. M. Abdo (2012): Effect of supplementing lactating goat rations with garlic, cinnamon or ginger oils on milk yield, milk composition and milk fatty acids profile. J. Life Sci. 4(1): 27-34. 
Kilic, U., M. Boga, M. Gorgulu and Z. Sahan. (2011). The effect of different compounds in some essential oils on in vitro gas production, J. Animal. Feed Sci., 20: 626-636.

Kongmun, P., M. Wanapat, P. Pakdee and C. Navanukraw. (2010). Effect of coconut oil and garlic powder on in vitro fermentation using gas production technique. Livestock Sci., 127: 38-44.

Kurniawati, A., Widod, W.T. Artom and L.M. Yusiati. (2017). The effect of cumin (cminum cyminuim) addition as source of essential oil on nutrient digestibility, VFA, ammonia and methan production. The $7^{\text {th }}$ International and seminar on tropical animal production. 12-14 september, Yogyakart, Indonesia.

Lewis, Y.S. (1984). Spices and herbs for the Food Industry, England: Food Trade press. 121-122.

Maynard, L. A.; J. K. Loosli; H. S. Hintz and R. G. Warner (1979): Animal Nutrition. McGraw-Hill Book Co. Inc.NY.

Miri, H., V. Tyagi, A.K. Ebrahimi and S. Hadi Mohini. (2013). Effect of cumin Cuminum cyminum seed extract on milk fatty acid profile and methane emission in lactating goat, 113:66-72.

Mirzaei-Aghsaghali, A., S.A. Syadati, H. Fathi, S. Rasouli, M. Sadaghian and M. Tarahomi. (2012). Garlic in ruminant feeding. Asian J. Biological. Sci., 5(7): 328-340.

Mohammadi, A. and E.A. Oshaghi. (2014). Effect of garlic on lipid profile and expression of LXR alpha in intestine and liver of hypercholesterolemic mice. J Diabetes Metab. Disord, 13: 20.

NRC (2007): 'Nutrient requirements of small ruminants sheep, goats, cervids, and new world camelids.' (National Academies Press: Washington, DC).

Nurdin, E. and Arief. (2009). The Effectiveness of Cumin as Natural Antioxidant to Improve Rumen Ecology of Mastitis Dairy Cow's. Animal Production. 11(3): 160- 164.

Park, J.H., Y.K. Park and E Park. (2009). Antioxidant and antigenotoxic effects of garlic (ALLIUM sativum L.)prepeared by different processing methods. Plant Food Hum Nutr., 64(4):244-249.

Patil, A.K., R.P.S. Baghel, S. Nayak, C.D. Malapure, K. Govil, D. Kumar and P.K. Yadav. (2017). Cumin (Cuminum cyminum): As a Feed Additive for Livestock. Journal of Entomology and Zoology Studies, 5(3): 365-369.

Patra-Kamra, D.N., R. Bhar, R. Kumar and N. Agarwal. (2011). Effect of Terminalia chebula and Allium sativum on in vivo methane emission by sheep. J. Anim. Physiol. Anim. Nutr., 95(2): 187191.

Pourali, M.; S. A. Mirghelenj and H. Kermanshahi (2010): Effect of garlic powder on productive performance and immune response of broiler chickens challenged with Newcastle disease virus. Global Veterineria. 4.

Rasoul, P., E. Anassori, Z. Zakeri and M. Tahmouzi. (2014). Effects of garlic supplementation on energy status of pre-partum Mahabadi goats. Veterinary Re. Forum, 5(3): 207-212.

Sabry A. A. E.; Sarah Y.A. Ahmed; Ola. F.A. Talkhan and E. A. Shalaby (2017): Effect of dietary supplementation by cinnamon and garlic powder on growth performance, interleukin- 6 and serum biochemistry in albino rat diets. Inter. J. Biol. Pharm. Sci., 6(2): 263-277

Sahli, F., C. Darej and N. Moujahed. (2018). Potential of white garlic powder (Allium sativum L.) to modify in vitro ruminal fermentation. South African Journal of Animal Science, 48 (2): 253-260.

Schäfer, G. and C.H. Kaschula. (2014). The immune modulation and anti-inflammatory effects of garlic organosulfur compounds in cancer chemoprevention. Anticancer.Agents Med. Chem,14: 233-241.

SPSS. (2008). Statistical package for Social Sciences, Statistics for Windows, Version 17.0. Released. Chicago, U.S.A.: SPSS Inc.

Toghyani, M. (2011): Effect of turmeric powder on performance, carcass traits, humoral immune responses, and serum metabolites in broiler chickens. Journal of Animal and Feed Sciences.663: 127. 


\title{
El Naggar and Ibrahim
}

Wanapat, M., A. Cherdthong, P. Pakdee and S. Wanapat. (2008b). Manipulation of rumen ecology by dietary lemongrass (Cymbopogon citrates Stapf) powder supplementation. J. Anim. Sci., 86: 34973503.

Wanapat, M., P Khejorsart, P. Pakdee and S. Wanapat. (2008a). Effect of supplementation of garlic powder on rumen ecology and digestibility of nutrients in ruminants. J. Science and Food Agriculture, 88: 2231-2237.

Wanapat, M., S. Kang, P. Khejornsat and S. Wanapat. (2013). Effects of plant herb combination supplementation on rumen fermentation and nutrient digestibility in beef cattle. Asian-Australasian J. Animal Sc., 26(8): 1127-1136.

Wanapat, M. and O. Pimpa. (1999). Effect of ruminant $\mathrm{NH}_{3}-\mathrm{N}$ levels on ruminal fermentation, purine derivative, digestibility and rice straw intake in swam buffalo. Asian Aust J Anim Sci., 12: 904907.

Warner, A.C.I. (1964). Production of volatile fatty acid in the rumen 1: Method of measurement .Nutr. Abstr. Review, 34: 339.

Yang, W.Z., C. Benchaar, B.N. Ametaj, A.V. Chaves, M,L. He and T.A. McAllister. (2007). Effects of garlic and juniper berry essential oils on ruminal fermentation and on the site and extent of digestion in lactating cows. J. Dairy Sci., 90:5671-5681.

Zafarian, R. and M. Manafi. (2013). Effect of Garlic Powder on Methane Production, Rumen Fermentation and Milk Production of Buffaloes. Annual Review \& Research in Biology, 3(4): 1013-1019.

\section{تاثير امداد عليقة الحملان بمسحوق الثوم أوالكمون على معاملات الهضم، قياسات سائل الكرش ومقاييس الام

\author{
سعاد النجار 1 وعماد الاين محمد إبراهيم²

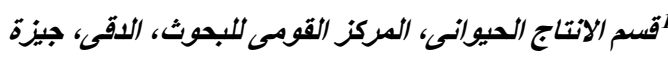

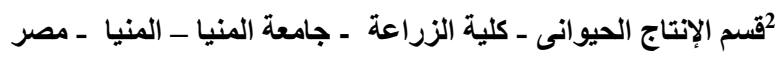

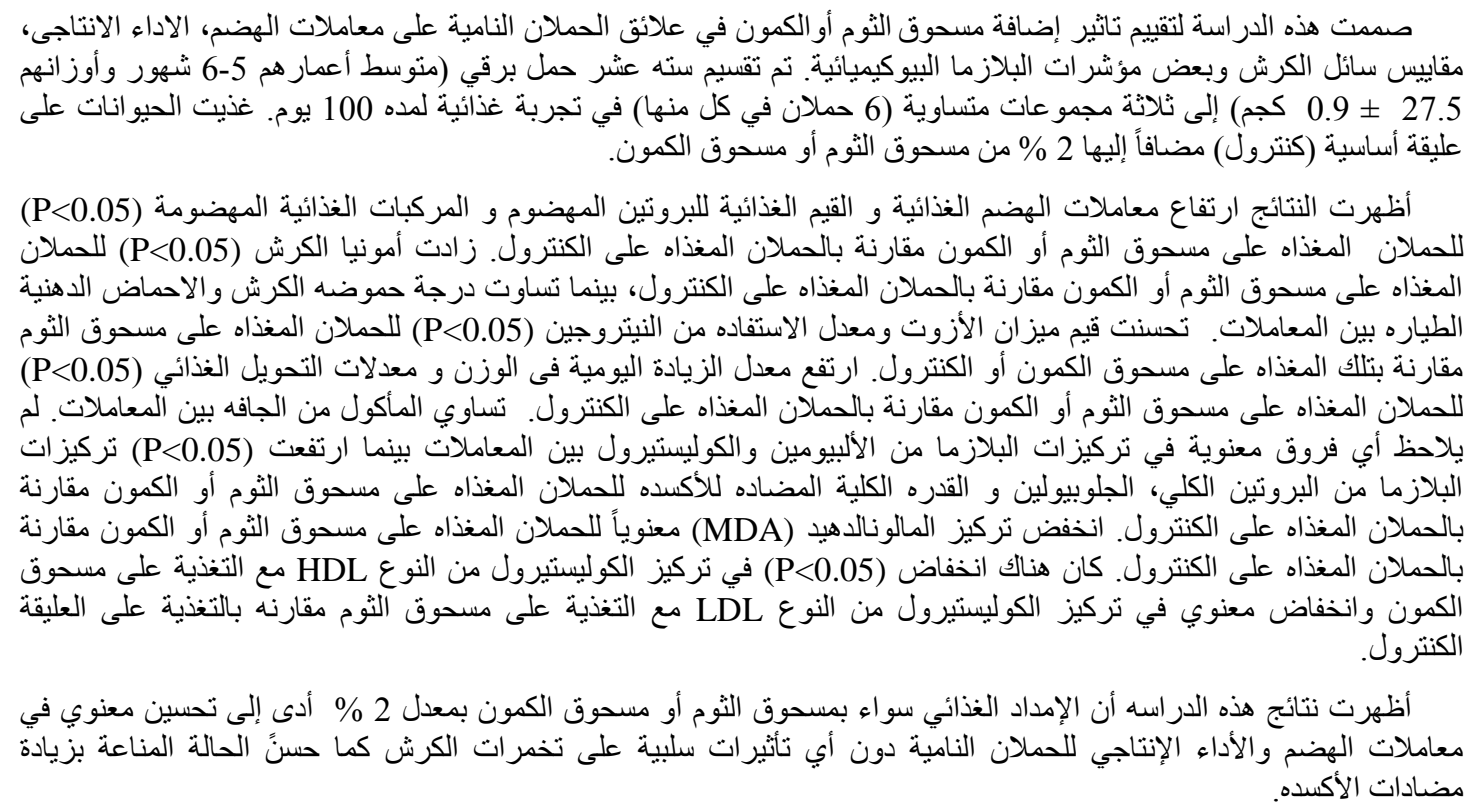

